\title{
The relationship between proton pump inhibitors and renal
} disease

Inibidores da bomba de prótons e sua relação com a doença renal

\section{Authors}

Carine Franco Morschel ${ }^{1}$ iD

Denise Mafra ${ }^{1}$

José Carlos Carraro Eduardo²

\author{
${ }^{1}$ Universidade Federal \\ Fluminense, Programa de Pós- \\ Graduação em Ciências Médicas, \\ Niterói, RJ, Brasil. \\ ${ }^{2}$ Universidade Federal \\ Fluminense, Faculdade de \\ Medicina, Niterói, RJ, Brasil.
}

Submitted on: 01/08/2018. Approved on: 05/03/2018.

\section{Correspondence to:}

Carine Franco Morschel.

E-mail: carine.morschel@gmail.com

DOI: 10.1590/2175-8239-JBN-2018-0021

\section{Abstract}

Proton pump inhibitors (PPIs) bind to enzyme $\mathrm{H}^{+} / \mathrm{K}^{+}$-ATPase and inhibit its activity in the stomach, thus decreasing the secretion of gastric acid. PPIs may trigger acute interstitial nephritis, a potentially severe adverse event commonly associated with acute kidney injury. Studies have found that prolonged use of PPIs may increase the risk of chronic kidney disease (CKD). The increase in prescription and inadequate use of this class of medication calls for studies on the effects of prolonged PPI therapy on renal function. Therefore, this review aimed to analyze recent studies on the matter and discuss the possible consequences of the long-term use of PPIs on renal function.

Keywords: Proton Pump Inhibitors; Renal Insufficiency, Chronic; Nephritis, Interstitial; Acute Kidney Injury.

Enzyme $\mathrm{H}^{+} / \mathrm{K}^{+}$-ATPase (proton pump), found in the canaliculi of the parietal cells of the stomach, plays a key role in the secretion of hydrochloric acid in the gastric lumen. The enzyme is activated by three distinct stimuli: histamine, gastrin, and acetylcholine. The production of acid occurs with the exchange of $\mathrm{K}^{+}$ (potassium) for $\mathrm{H}^{+}$(hydrogen) in an ATPconsuming process. ${ }^{1,2}$

PPIs were designed to block acid secretion in the stomach and increase the $\mathrm{pH}$ of the gastric juice. They inhibit the action of enzyme $\mathrm{H}^{+} / \mathrm{K}^{+}$-ATPase and prevent the exchange of $\mathrm{K}^{+}$for $\mathrm{H}^{+}$, while differentiating themselves from other drugs used to treat gastric diseases for also

\section{Resumo}

Os Inibidores da Bomba de Prótons (IBPs) são medicamentos que inibem a enzima $\mathrm{H}^{+} / \mathrm{K}^{+}$-ATPase no estômago, diminuindo a secreção gástrica. Esses medicamentos podem desencadear nefrite intersticial aguda, evento adverso potencialmente grave e que pode cursar com lesão renal aguda. Além disso, pesquisadores têm observado que o uso prolongado de IBPs pode também aumentar o risco de progressão da doença renal crônica (DRC). Com o crescimento da prescrição e o uso inadequado dessa classe de medicamentos, torna-se importante o estudo dos efeitos do uso prolongado dos IBPs sobre a função renal. Assim, esta revisão pretende abordar os recentes estudos sobre o tema e discutir as possíveis consequências que o uso contínuo dos inibidores da bomba de prótons pode causar na função renal.

Palavras-chave: Inibidores da Bomba de Prótons; Insuficiência Renal Crônica; Nefrite Intersticial; Lesão Renal Aguda.

inhibiting the last step in the production of hydrochloric acid. This process enhances the potency of inhibition, making PPIs the current drug of choice..$^{2-4}$ PPIs inhibit the enzyme by merging with its receptor and covalently binding to cysteine residues known as irreversible inhibitors (Figure 1). After the reaction, the proton pump cannot regenerate and acid production occurs only after the synthesis of new enzymes. Irreversible inhibition ensures the medication is active for 24 to 48 hours. $3,5,6$

PPIs are weak acids that share the same basic structure of their molecules, differentiating only in their radicals (Figure 2). They are inactive when administered, 
Figure 1. Mode of action of proton pump inhibitors in parietal cells.

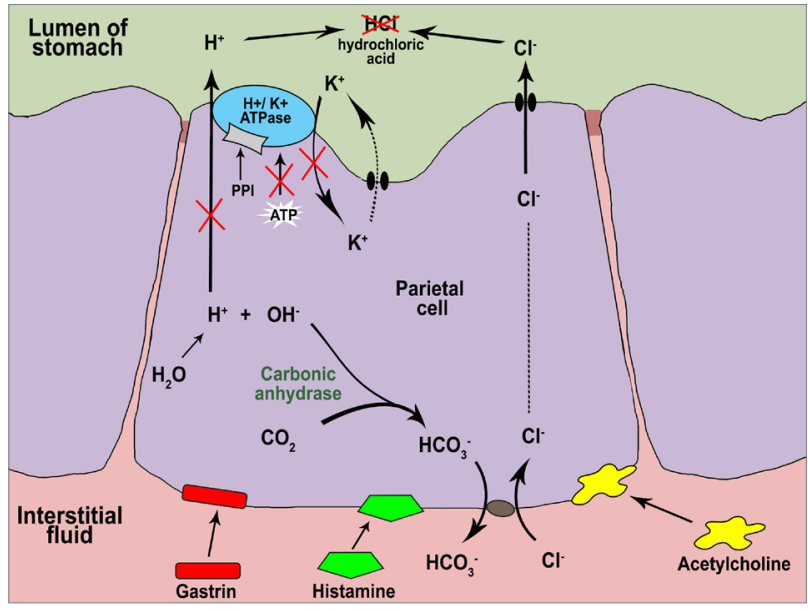

Figure 2. Molecular structures of the proton pump inhibitors available in Brazil.

$$
\mathrm{H}_{3} \mathrm{CO}
$$
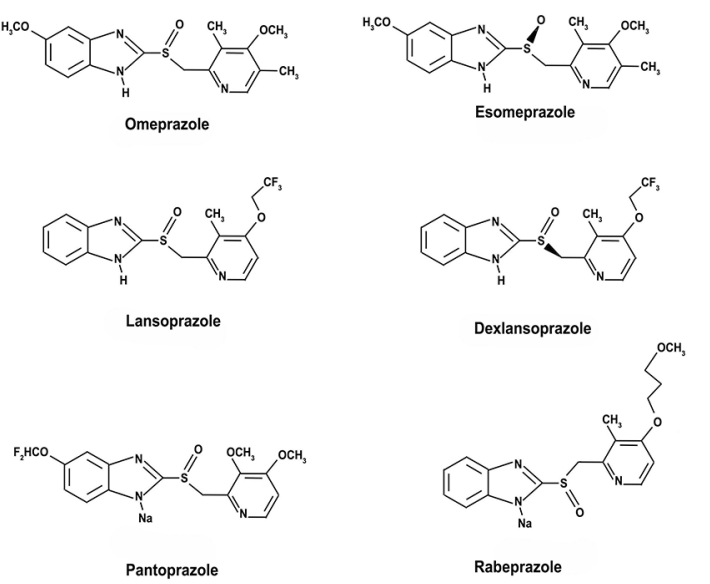

and under acidic $\mathrm{pH}$ will form sulfamide derivatives or sulfenic acid. PPIs receive gastro-resistant coating to prevent the activation - and thus degradation - of the drug before it arrives at the targeted site. With a plasma half-life of one to two hours, they are quickly absorbed and activated after administration. PPIs are metabolized by liver cytochrome P450 enzymes, which may affect the biotransformation of other medications. In addition, changes in stomach acidity may alter the absorption of other drugs. ${ }^{1-3,7}$

Omeprazole was the first to be synthesized and is still the most often used drug of this class of medications. ${ }^{8}$ PPIs are prescribed to treat gastric diseases such as gastric and duodenal ulcers, gastroesophageal reflux disease, and erosive esophagitis. ${ }^{9}$

However, as the years went by PPIs began to be prescribed injudiciously to patients outside the scope of indication, for periods longer than recommended, and taken by self-medicating individuals. ${ }^{4,10}$ In addition, the drug is often used to treat digestive manifestations or to prevent symptoms derived from the use of other medications. All such factors have included PPIs in the list of the most used medications in the world. ${ }^{11,12,13}$

Side effects are rare. The most common include headache, nausea, constipation, flatulence, diarrhea, skin rash, and dizziness. ${ }^{4,14}$ Although infrequent, there is growing evidence of other adverse events connected to PPIs such as bone fractures, pneumonia, dementia, hypomagnesemia, and renal diseases including acute interstitial nephritis (AIN), acute kidney injury (AKI), and chronic kidney disease (CKD) more recently. ${ }^{15-17}$

AIN ranks among the rare adverse events more consistently associated with PPIs. This immunemediated reaction involves the interstitium and the renal tubules. It may be induced by autoimmune disease, blood disorders, infection, and medication. At first, tubule epithelial cells are injured, and subsequently a lymphocytic inflammatory infiltrate containing predominantly $\mathrm{T}$ cells is observed. Renal scarring may initiate as a consequence of the spread of the infiltrate, followed by decrease in renal function. In drug-induced AIN, if no improvement is seen after the discontinuation of the suspected drug and the introduction of corticosteroids, patients may progress to chronic kidney disease with interstitial fibrosis and tubular atrophy. ${ }^{18,19}$

Although nonspecific symptoms such as malaise, fatigue, weakness, arthralgia, myalgia, fever, and skin rash may occur and confused AIN with other diseases, eosinophilia is a frequent finding. AIN has been estimated to account for eight percent of the cases of acute kidney injury, $70-90 \%$ of which induced by medication. The main drug classes linked to AIN are antibiotics, PPIs, and non-steroid anti-inflammatory drugs. ${ }^{20,21}$

A number of studies published subsequently to the first case study of 1992 supported the link between AIN and use of PPIs.22-24 Antoniou et al. reported a three-fold increase in the risk of AIN among individuals taking PPIs (95\% CI 1.47-6.14; n $=290,592) \cdot{ }^{25}$ The origin of the renal inflammation seen in these cases has not been established, but the accumulation of PPIs and/or their metabolites in the interstitial tubules and the ensuing immune response have been considered a plausible explanation. ${ }^{15}$

The time until the onset of PPI-induced AIN ranges between hours and months. There is no 
evident relationship between dosage, latency, time to recovery, age or sex, indicating that this is a condition of immune origin. ${ }^{26}$ Hypersensitivity reaction is apparently a common effect of PPIs, since there are reports of AIN associated with all medications in this drug class. ${ }^{22}$

Differently from AIN induced by other drugs, patients rarely present with the characteristic triad seen in hypersensitivity reaction (fever, skin rash, and eosinophilia). Urinary findings include sterile leukocyturia, hematuria, and urinary eosinophils. ${ }^{27}$ Diagnosis is based on lab and imaging tests and clinical examination, although tests do not necessarily lead to accurate diagnosis. ${ }^{19}$

Treatment to reverse acute disease includes the discontinuation of PPIs, the administration of corticosteroids, and possibly the prescription of renal replacement therapy.21,28 Despite these interventions, over half of the patients cannot fully recover their renal function after AIN. A few are able to return to baseline serum creatinine $(\mathrm{Cr})$ levels, which are slightly increased. Moreover, the estimated glomerular filtration rates of patients recovering from AKI remain below baseline levels..$^{27,29}$

The fast decrease of renal function derived from tubulointerstitial lesions may promote the onset of AKI. The investigation of the causes of this condition led to the diagnosis of AIN, which is usually confirmed after renal biopsy. When biopsy is contraindicated, patients have the option of undergoing Gallium-67 scintigraphy, a test with great use in the differentiation of AIN from acute tubular necrosis. ${ }^{30,31}$ Approximately $30 \%$ of the patients who recover from AKI remain at increased risk of having CKD. ${ }^{32,33}$

Hypomagnesemia is another side effect derived from the use of PPIs. A study enrolling 9,818 individuals associated PPIs to a twofold increase in the risk of developing hypomagnesemia $195 \%$ CI 1.36-2.93). The mechanism behind the decrease in magnesium $(\mathrm{Mg})$ levels by PPIs has not been entirely elucidated. Low urinary concentrations suggest that $\mathrm{Mg}$ depletion occurs in the gastrointestinal tract. Evidence indicates that low blood levels of $\mathrm{Mg}(<0.7$ $\mathrm{mmol} / \mathrm{L}$ ) are associated with $\mathrm{CKD} .^{20}$

AIN causes acute inflammation and tubulointerstitial damage, which in the long term lead to interstitial fibrosis and chronic interstitial nephritis. Chronic interstitial nephritis may ultimately lead to CKD and, in severe cases, to renal failure. Figure 3 illustrates a hypothesis on how PPIs may cause renal disease..$^{15,20,27}$

Although few authors have looked into the possible association between PPIs and CKD, the studies published to date have reported increased risk of progression to advanced-stage CKD. A plausible mechanism to explain these findings is still unclear, and authors have considered it a consequence of progression to AIN. The literature indicates that PPIs should be prescribed with caution to patients with CKD, accompanied by creatinine level monitoring where needed. ${ }^{34,17}$

The first to suggest an association between PPIs and CKD were Lazarus et al. in 2016. The authors analyzed whether PPIs alone were and histamine H2-receptor antagonists $\left(\mathrm{H}_{2}\right)$ were not a risk factor for CKD. The authors used the cohort from the Atherosclerosis Risk in Communities study with 10,482 participants, and later repeated the study with 248,751 individuals served by the Geisinger Health System. The outcomes were similar in the two groups, and the use of PPIs was associated with increased risk and 1.17 to 1.5 times greater risk of CKD. The association was verified only with PPIs. ${ }^{35}$

Other authors explored the theme in the same year. Peng et al. performed a study and analyzed the association between PPIs and risk of progression of renal disease. The study enrolled 7,616 individuals split into two matched groups featuring patients with CKD and controls. The authors found that use of PPIs was more prevalent among patients with CKD, and that the risk of CKD was 1.88 times greater among individuals on PPIs. ${ }^{34}$

Arora et al. (2016) conducted a study based on the data of 99,269 individuals from the New York/ New Jersey Veterans Affairs Health Care and concluded that patients on PPIs had a greater incidence of CKD and higher mortality risk (OR 1.76; 95\% CI 1.67-1.84). ${ }^{36}$

Xie et al. published a paper associating PPIs to CKD and progression to renal failure. Participants on PPIs $(n=173,321)$ or H2RA $(n=20,270)$ were selected and followed for five years. The study revealed that patients on PPIs were at 1.28 times greater risk of developing CKD and 1.96 times greater risk of progressing to renal failure. As in previous studies, no association was found between H2RA and renal disease. ${ }^{37}$ 
Figure 3. Hypothesis explaining the possible correlation between PPIs and renal disease.

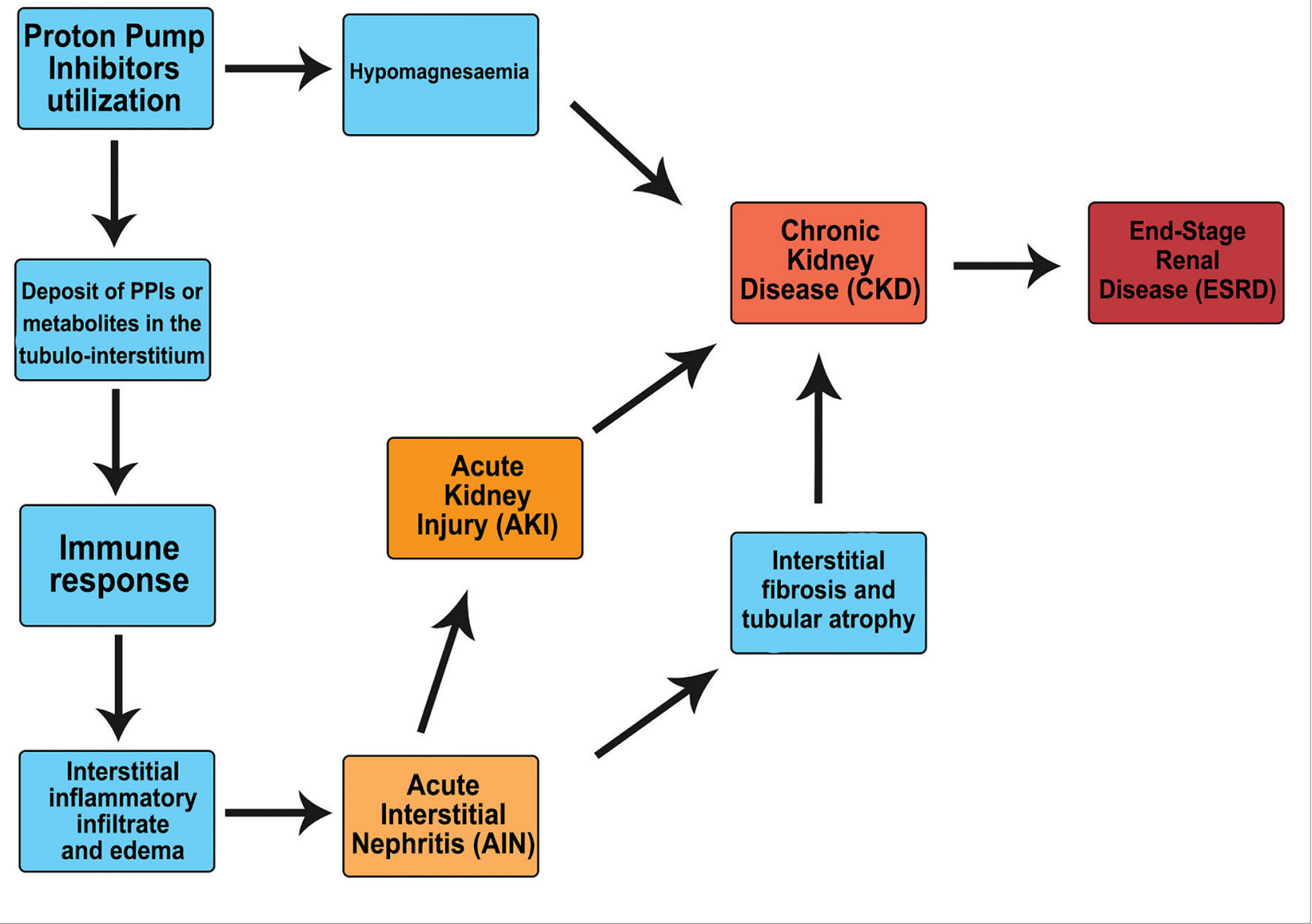

In 2017, Xie et al. published another study based on data from the US Veterans Affairs Department. In this study, 144,032 patients on acid suppression therapy (PPIs and H2RA) were analyzed for AKI renal outcomes without intervention. The occurrence of CKD was 1.26 times greater among patients on PPIs. Similar results were found for declines greater than $30 \%$ in the estimated glomerular filtration rate (eGFR) (1.22-time increase) and for advanced-stage CKD or decline of more than $50 \%$ in the eGFR (1.30-time increase). ${ }^{38}$

Klatte et al. (2017) published a paper with data gathered from the Stockholm CREAtinine Measurements made between 2006 and 2011. In the study design, new users of PPIs $(\mathrm{n}=105,305)$ and H2RA ( $\mathrm{n}=9,578)$ were compared for risk of developing CKD. Creatinine levels and CKD progression based on two factors, namely doubling the creatinine level or having a decrease greater than $30 \%$ in the eGFR, were analyzed. The results for PPI users revealed risk 1.26 times greater for the two endpoints. Another important finding in this study showed that only $16 \%$ of the PPI users had precise indication for treatment. ${ }^{39}$

It is important to note that all publications looking into the matter are observational studies based on retrospective data, thus subject to significant bias. To this date, randomized clinical trials have not been performed to shed more light on the issue. With that in mind, Tomlinson et al. (2017) stressed that despite the correlations described between the use of PPIs and CKD progression, the evidence to support this causal relationship is not strong. The authors suggested that more detailed studies are required to confirm the increase in risk. They added that patients have been taking PPIs for a long time without specific treatment indication and that the cost-effectiveness of these medications should be assessed. ${ }^{40}$

The associations between AIN, AKI, and PPIs, although more significant in the literature than with CKD are, likewise, the topic of retrospective studies, from which a causal relationship cannot be extracted. ${ }^{18,25,41}$ However, the correlation between PPIs and renal disease is plausible. Randomized 
clinical trials are needed to consolidate the possible effects of this drug class on renal function.

Several studies have alluded to the inadequate administration of PPIs, often the object of off-label therapies, unnecessarily long courses of treatment, and self-medication. ${ }^{13,42-44}$ Although patients in Brazil are required to produce a medical prescription to buy PPIs, drugs in this class can be unreservedly acquired in drugstores all over the nation. ${ }^{15,16,45,46}$ In this context, healthcare workers and the general population must be made aware of the risks associated with the use of medication without professional advice and its ensuing impacts on public health. ${ }^{47}$

The medical relevance, along with the efficacy and safety of PPIs, cannot be denied. Proper use of the medication must be enforced in accordance with therapeutic guidelines. The benefits yielded by PPIs must be monitored, and drug therapy discontinued as soon as it is no longer needed. ${ }^{15,48}$ In clinical practice, Nehra, Alexander, and Loftus suggested that the eGFR be monitored annually, as recommended for patients on potentially nephrotoxic drugs. ${ }^{49}$

\section{AcKNOWLEDgeMENTS}

The authors would like to thank the Coordenação de Aperfeiçoamento de Pessoal de Nível Superior (CAPES), the Conselho Nacional de Pesquisa (CNPq), and the Fundação de Amparo à Pesquisa do Estado do Rio de Janeiro (FAPERJ) for providing financial support to this study.

\section{References}

1. Shin JM, Sachs G. Pharmacology of proton pump inhibitors. Curr Gastroenterol Rep 2008;10:528-34.

2. Roche VF. The chemically elegant proton pump inhibitors. Am J Pharm Educ 2006;70:101.

3. Strand DS, Kim D, Peura DA. 25 Years of Proton Pump Inhibitors: A Comprehensive Review. Gut Liver 2017;11:2737.

4. Braga MP, da Silva C de B, Adams AIH. Inibidores da bomba de prótons: revisão e análise farmacoeconômica. Saúde (Santa Maria) 2011;37:19-32.

5. Brinkworth MD, Aouthmany M, Sheehan M. Histamine 2 Receptor Antagonists and Proton Pump Inhibitors. Dermatitis 2016;27:100-9.

6. Shin JM, Kim N. Pharmacokinetics and pharmacodynamics of the proton pump inhibitors. J Neurogastroenterol Motil 2013;19:25-35.

7. Câmara de Regulação do Mercado de Medicamentos C. Preços máximos de medicamentos por princípio ativo [Internet]. Anvisa. 2017 [cited 2017 Aug 24]. Available from: http://portal.anvisa.gov.br/documents/374947/2829072/ LISTA+CONFORMIDADE_2017-08-22.pdf/f377526c-cfd04a40-ab63-f5a04b8d7b3c.

8. Brewster UC, Perazella MA. Acute kidney injury following proton pump inhibitor therapy. Kidney Int 2007;71:589-93.
9. Nadri Q, Althaf MM. Granulomatous tubulointerstitial nephritis secondary to omeprazole. BMJ Case Rep 2014;2014. pii: bcr2014203842.

10. George CJ, Korc B, Ross JS. Appropriate Proton Pump Inhibitor Use Among Older Adults: A Retrospective Chart Review. Am J Geriatr Pharmacother 2008;6:249-54.

11. Yadlapati R, Kahrilas PJ. When is proton pump inhibitor use appropriate? BMC Med 2017;15:36.

12. Wannmacher L. Inibidores da bomba de prótons: Indicações racionais. Uso Racion Medicam Temas Selecionados 2004;2:16

13. Scarpignato C, Gatta L, Zullo A, Blandizzi C; SIF-AIGO-FIMMG Group; Italian Society of Pharmacology, the Italian Association of Hospital Gastroenterologists, and the Italian Federation of General Practitioners. Effective and safe proton pump inhibitor therapy in acid-related diseases - A position paper addressing benefits and potential harms of acid suppression. BMC Med 2016;14:179.

14. Aronson JK. Inhibiting the proton pump: mechanisms, benefits, harms, and questions. BMC Med 2016;14:172.

15. Eusebi LH, Rabitti S, Artesiani ML, Gelli D, Montagnani M, Zagari RM, et al. Proton pump inhibitors: Risks of long-term use. J Gastroenterol Hepatol 2017;32:1295-302.

16. Nochaiwong S, Ruengorn C, Awiphan R, Koyratkoson K, Chaisai C, Noppakun K, et al. The association between proton pump inhibitor use and the risk of adverse kidney outcomes: a systematic review and meta-analysis. Nephrol Dial Transplant 2018;33:331-42.

17. Schnoll-Sussman F, Katz PO. Clinical Implications of Emerging Data on the Safety of Proton Pump Inhibitors. Curr Treat Options Gastroenterol 2017;15:1-9.

18. Nast CC. Medication-Induced Interstitial Nephritis in the 21st Century. Adv Chronic Kidney Dis 2017;24:72-9.

19. Perazella MA. Clinical Approach to Diagnosing Acute and Chronic Tubulointerstitial Disease. Adv Chronic Kidney Dis 2017;24:57-63.

20. Malavade P, Hiremath S. Proton pump inhibitors: More Indigestion than Relief? Indian J Nephrol 2017;27:249-57.

21. Ramachandran R, Kumar K, Nada R, Jha V, Gupta K, Kohli H. Drug-induced acute interstitial nephritis: A clinicopathological study and comparative trial of steroid regimens. Indian J Nephrol 2015;25:281-6.

22. Sampathkumar K, Ramalingam R, Prabakar A, Abraham A. Acute interstitial nephritis due to proton pump inhibitors. Indian J Nephrol 2013;23:304-7.

23. Torregrosa E, Rovira R, Calvo C, Hernández-Jaras J, Maduell F, García H. Nefritis intersticial aguda por omeprazol. Nefrología 2004;24:61-3.

24. Simpson IJ, Marshall MR, Pilmore H, Manley P, Williams L, Thein $\mathrm{H}$, et al. Proton pump inhibitors and acute interstitial nephritis: report and analysis of 15 cases. Nephrology (Carlton) 2006;11:381-5.

25. Antoniou T, Macdonald EM, Hollands S, Gomes T, Mamdani MM, Garg AX, et al. Proton pump inhibitors and the risk of acute kidney injury in older patients: a population-based cohort study. CMAJ Open 2015;3:E166-71.

26. Raghavan R, Shawar S. Mechanisms of Drug-Induced Interstitial Nephritis. Adv Chronic Kidney Dis 2017;24:64-71.

27. Moledina DG, Perazella MA. PPIs and kidney disease: from AIN to CKD. J Nephrol 2016;29:611-6.

28. Härmark L, van Der Wiel HE, de Groot MCH, van Grootheest AC. Proton pump inhibitor-induced acute interstitial nephritis. Br J Clin Pharmacol 2007;64:819-23.

29. Torpey N, Barker T, Ross C. Drug-induced tubulo-interstitial nephritis secondary to proton pump inhibitors: experience from a single UK renal unit. Nephrol Dial Transplant 2004;19:14416.

30. Graham F, Lord M, Froment D, Cardinal H, Bollée G. The use of gallium-67 scintigraphy in the diagnosis of acute interstitial nephritis. Clin Kidney J 2016;9:76-81. 
31. Kodner CM, Kudrimoti A. Diagnosis and management of acute interstitial nephritis. Am Fam Physician 2003;67:2527-34.

32. KDIGO. KDIGO Clinical Practice Guideline for Acute Kidney Injury. Kidney Int Suppl 2012;2:1-138.

33. Praga M, González E. Acute interstitial nephritis. Kidney Int 2010;77:956-61.

34. Peng YC, Lin CL, Yeh HZ, Chang CS, Wu YL, Kao CH. Association Between the Use of Proton Pump Inhibitors and the Risk of ESRD in Renal Diseases: A Population-Based, CaseControl Study. Medicine (Baltimore) 2016;95:e3363.

35. Lazarus B, Chen Y, Wilson FP, Sang Y, Chang AR, Coresh J, et al. Proton Pump Inhibitor Use and the Risk of Chronic Kidney Disease. JAMA Intern Med 2016;176:238-46.

36. Arora P, Gupta A, Golzy M, Patel N, Carter RL, Jalal K, et al. Proton pump inhibitors are associated with increased risk of development of chronic kidney disease. BMC Nephrol 2016;17:112.

37. Xie Y, Bowe B, Li T, Xian H, Balasubramanian S, Al-Aly Z. Proton Pump Inhibitors and Risk of Incident CKD and Progression to ESRD. J Am Soc Nephrol 2016;27:3153-63.

38. Xie Y, Bowe B, Li T, Xian H, Yan Y, Al-Aly Z. Long-term kidney outcomes among users of proton pump inhibitors without intervening acute kidney injury. Kidney Int 2017;91:1482-94.

39. Klatte DCF, Gasparini A, Xu H, de Deco P, Trevisan M, Johansson ALV, et al. Association Between Proton Pump Inhibitor Use and Risk of Progression of Chronic Kidney Disease. Gastroenterology 2017;153:702-10.

40. Tomlinson LA, Fogarty DG, Douglas I, Nitsch D. Pharmacoepidemiology for nephrologists: do proton pump inhibitors cause chronic kidney disease? Nephrol Dial Transplant 2017;32:ii40-ii46.
41. Muriithi AK, Leung N, Valeri AM, Cornell LD, Sethi S, Fidler $\mathrm{ME}$, et al. Biopsy-proven acute interstitial nephritis, 19932011: A case series. Am J Kidney Dis 2014;64:558-66.

42. Braga DC, Bortolini SM, Stroher CK, Cassol M, Bordignon $\mathrm{S}$, Byczkovski T. Uso crônico de inibidores da bomba de prótons na atenção primária. GED Gastroenterol Endosc Dig 2014;33:125-8.

43. Garcia M, Saracho R, Jaio N, Vrotsoukanari K, Aguirre C. Inadequate drug prescription and the rise in drug-induced acute tubulointerstitial nephritis incidence. NDT Plus 2010;3:555-7.

44. Divisón Garrote JA, Escobar Cervantes C. Uso de inhibidor de la bomba de protones y el riesgo de enfermedad renal crónica. Semergen 2017;43:230-1.

45. Yang Y, George KC, Shang WF, Zeng R, Ge SW, Xu G. Proton-pump inhibitors use, and risk of acute kidney injury: a meta-analysis of observational studies. Drug Des Devel Ther 2017;11:1291-9.

46. Brasil. Ministério da Saúde. Anvisa. Instrução Normativa N.11 - Lista de medicamentos isentos de prescrição [Internet]. 2016 [cited 2017 Oct 10]. Available from: http://pesquisa. in.gov.br/imprensa/jsp/visualiza/index.jsp?jornal=1\&pagina $=$ 99\&data $=30 / 09 / 2016$

47. Pereira JR, Soares L, Hoepfner L, Kruger KE, Guttervil ML, Tonini KC, et al. Riscos da Automedicação: Tratando o problema com conhecimento. Joinville: Univille; 2008. 20 p.

48. Toth-Manikowski S, Grams ME. Proton Pump Inhibitors and Kidney Disease-GI Upset for the Nephrologist? Kidney Int Rep 2017;2:297-301.

49. Nehra AK, Alexander JA, Loftus CG, Nehra V. Proton Pump Inhibitors: Review of Emerging Concerns. Mayo Clin Proc 2018;93:240-6. 